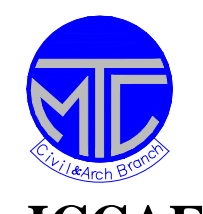

Military Technical College

Kobry Elkobbah,

Cairo, Egypt 7th International Conference

On Civil \& Architecture

Engineering

\title{
Improvement Concrete Barriers to Resist Pentration of Missiles
}

\author{
Maj. Gen. Dr.| Ahmed A. Aggour ${ }^{1}$ \\ Col. Dr.l Essam Eltehiwy ${ }^{2}$ \\ Maj. Eng.। Hesham F. Salem ${ }^{3}$
}

\begin{abstract}
Concrete needs more investigations and development to improve its properties and provide it high performance to resist impact loads, penetration and perforation which resulted from projectiles of modern destructive weapons, which affect many military structures such as slabs of airports, runways, protective shelters, and fortification structures.

An experimental program was carried out to investigate the efficiency of two strengthening techniques, using additives to fresh concrete using hooked-end steel fibers with aspect ratio ( $\mathrm{l} / \mathrm{d}=50)$, and new shape of steel fibers (spiral steel fiber) of spiral diameter $15 \mathrm{~mm}$ with wire diameter $1 \mathrm{~mm}$. The steel fibers were added with different volume fractions $(1 \%, 2 \%$ and $3 \%)$ for both hooked-ends and spiral steel fibers. The specimens were tested to study the mechanical properties and behavior of concrete, which included penetration depths, crater diameters.

It was observed that adding steel fibers to plain concrete prevents its shattering, disintegration, and also decreases spalling when opposed to hard projectiles. Also adding steel fibers "hooked-ends" with 1\% volume content improves penetration resistance to hard missiles and reduce penetration depth about $30 \%$, while there is no significant reduction in penetration depth when increase fibers fraction to $2 \%$ "by volume". But there is descending in penetration resistance if we increase steel fibers content to 3\% "by volume".
\end{abstract}

KEYWORDS: Concrete; Steel fiber-reinforced concrete; Penetration; Projectile impact

1- professor of testing and properties of materials, Military Technical College

2- lecturer of testing and properties of materials, Military Technical College

3- Researcher, Military Technical College

\section{Introduction}

One of the problems of a cement-based matrix is the inherently brittle type of failure, which occurs under tensile stress systems or impact loading. A major reason for the growing interest in the performance of fibers in cement-based 
materials is the desire to increase the toughness or tensile properties of the basic matrix. Concrete is inherently a brittle material with little toughness, as measured by the area under the stress-strain curve. Reinforcement is necessary to provide ductility after cracking. Fiber reinforcement incorporated in the plastic concrete will typically increase the flexural and tensile strength of plain concrete although there is little substantial increase in compression strength. Steel fibers have been the primary type of fiber used in practice.

The steel fiber used in this research has a commercial name (harcofiber) provided from Master Chemicals Company (MC).

- Description:-

MC-Harco Fiber S.F is a steel fiber deformed circular shape of low carbon steel material. Figure (1) shows both two shapes of steel fibers that used in this study; first shape was Hooked-end and second shape was spiral shape "innovative shape".

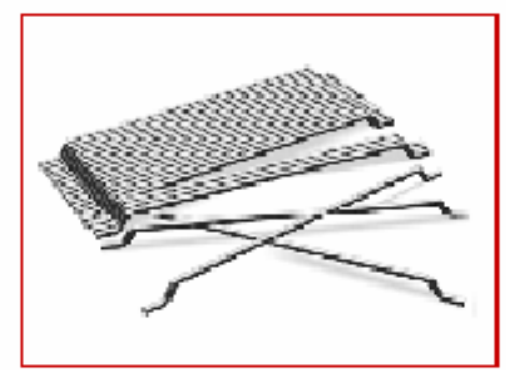

(a) MC-Harco Fiber

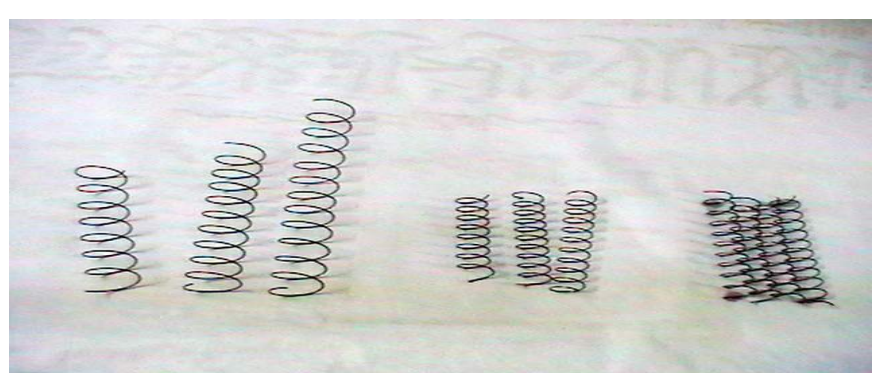

(b) Spiral steel fiber

Fig. (1) (a) MC-Harco Fiber (hooked-end), (b) Spiral steel fiber

- Chemical composition:-

$\begin{array}{lll}\text { Carbon (C) } & : & 0.08-0.13 \\ \text { Manganese (Mn) } & & 0.30-0.60 \\ \text { Phosphorus (P) } & : & 0.040 \text { max } \\ \text { Sulphur (S) } & : & 0.050 \max \end{array}$

- Technical data:-

$\begin{array}{ll}\text { Specific gravity } & : 7.8 \\ \text { Tensile strength } & : 800-1500 \mathrm{MPa} \\ \text { Length } & : 50 \mathrm{~mm} \\ \text { Diameter } & : 1 \mathrm{~mm} \\ \text { Hooked end } & : 2-3 \mathrm{~mm} \\ \text { Spiral (new shape) } & : 15 \mathrm{~mm} \text { (diameter of spiral) } \\ \text { Wire diameter } & : 1 \mathrm{~mm} \text { (in spiral shape) }\end{array}$

\section{Reserch significance}

This study is based on an experimental program. To fulfill the improvement properties of concrete subjected to impact loading with very high speed to resist penetration of missiles. The protected layer (Barrier) formed out of modified plain concrete slabs by using steel fibers (SF), can help in protecting buried structure and minimize the hazards of protective layers disintegration. The modified concrete will 
be tested to evaluate its mechanical behavior and response against penetration, dynamic and impact loading action.

\section{Experimental program Concrete mix design}

The concrete mix was designed according to the American concrete institute (ACI) method to give an average strength of $35 \mathrm{~N} / \mathrm{mm}^{2}$ after 28 days. Water/cement ratio was constant $(W / C=0.45)$. Cement which used was ordinary Portland cement with a density of $3.15 \mathrm{t} / \mathrm{m}^{3}$ and its nominal content was $400 \mathrm{~kg} / \mathrm{m}^{3}$. Fine aggregate was siliceous sand with a specific gravity of $2.65 \mathrm{t} / \mathrm{m}^{3}$. Coarse aggregate was crushed dolomite stone of specific gravity $2.65 \mathrm{t} / \mathrm{m}^{3}$ and with maximum particle size $6.3 \mathrm{~mm}$. The superplasticizer was $1 \%$ by weight of cement content to control the workability of concrete. The amounts of steel fiber and spiral steel fiber were $V_{f}=1 \%, 2 \%$ and $3 \%$ by volume of total concrete mix $\left(78,156\right.$ and $\left.234 \mathrm{~kg} / \mathrm{m}^{3}\right)$. The aspect ratio $(\mathrm{l} / \mathrm{d})$ of steel fiber (SF) was $=50$ (where the fiber length $=50 \mathrm{~mm}$ and its diameter $=1 \mathrm{~mm}$ ). Also wire diameter of spiral steel fiber $(\mathrm{SSF})=1 \mathrm{~mm}$ and diameter of spiral $=15 \mathrm{~mm}$. The mix proportions by weight were:-

Cement: Sand : Crushed dolomite: W/C ratio : Superplasticizer (Spc)

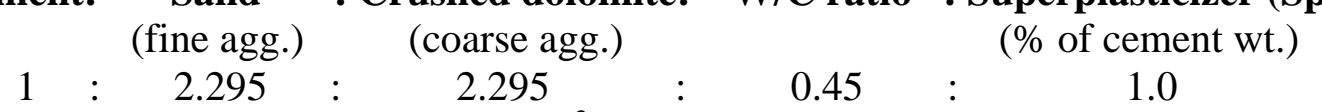

The mix proportions by weight for $1 \mathrm{~m}^{3}$ of concrete are shown in table (1).

Table (1) Proportions by weight for $1 \mathrm{~m}^{3}$ of concrete

\begin{tabular}{|c|c|c|c|c|c|}
\hline $\begin{array}{c}\text { Cement } \\
\mathbf{( k g})\end{array}$ & $\begin{array}{c}\text { Sand } \\
\mathbf{( k g}\end{array}$ & $\begin{array}{c}\text { Crushed dolomite } \\
\mathbf{( k g )}\end{array}$ & $\begin{array}{c}\text { Steel Fiber } \\
\mathbf{( k g )}\end{array}$ & $\begin{array}{c}\text { Water } \\
\mathbf{( k g )}\end{array}$ & $\begin{array}{c}\text { Spc } \\
\mathbf{( k g})\end{array}$ \\
\hline 400 & 918 & 918 & 0 & 180 & 4 \\
\hline 400 & 900.62 & 900.62 & 78 & 180 & 4 \\
\hline 400 & 887.37 & 887.37 & 156 & 180 & 4 \\
\hline 400 & 874.12 & 874.12 & 234 & 180 & 4 \\
\hline
\end{tabular}

Steel fibers, spiral fibers is variable from (0-3) \% by volume of concrete

\section{Specimens}

In this study, the main concern was primarily the effects of the concrete additives (fibers content, shape of fibers) which only affect the strength and other mechanical properties of concrete. The specimens include cubes, beams and slabs with corresponding dimensions of (150x150x150 mm), (100x100x500 mm) and (500x500x200 mm) respectively. The specimens were divided into three main groups (plain concrete "PC", steel fiber concrete "SFC" and spiral steel fiber concrete "SSFC") as shown in table (2).

Table (2) The tests required for different types of specimens 


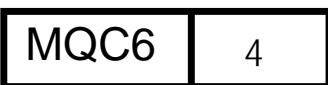

\begin{tabular}{|c|c|c|}
\hline $\begin{array}{c}\text { Type } \\
\text { Of } \\
\text { specimens } \\
\end{array}$ & $\begin{array}{c}\text { Type } \\
\text { Of } \\
\text { concrete } \\
\end{array}$ & $\begin{array}{c}\text { Test } \\
\text { Required }\end{array}$ \\
\hline $\begin{array}{c}\text { Cube } \\
(150 \times 150 \times 150 \mathrm{~mm})\end{array}$ & \multirow{3}{*}{$\begin{aligned}> & \mathrm{PC} \\
> & \mathrm{SFC} \\
& (1 \%, 2 \%, 3 \%) \\
> & \mathrm{SSFC} \\
& (1 \%, 2 \%, 3 \%)\end{aligned}$} & - Compressive strength \\
\hline $\begin{array}{c}\text { Beam } \\
(100 \times 100 \times 500 \mathrm{~mm})\end{array}$ & & $\begin{array}{l}\text { - Flexural strength (MOR) } \\
\text { - Impact resistance }\end{array}$ \\
\hline $\begin{array}{c}\text { Slab } \\
(500 \times 500 \times 200 \mathrm{~mm})\end{array}$ & & $\begin{array}{l}\text { - Gas gun test } \\
\text { (Penetration of missile) }\end{array}$ \\
\hline
\end{tabular}

\section{Mechanical Tests}

\section{Compressive strength test}

These tests were carried out according to the British Standard Specification (BS).

\section{Tensile strength test}

The common methods for estimating the tensile strength of concrete were the splitting tensile test, and the flexural test.

\section{Flexural strength test (MOR)}

Flexural test is the way of estimating the tensile strength of concrete (ASTM C78). The specimens “ beams” were tested in flexure in third-point loading.

\section{Dynamic Impact resistance test}

In this investigation impact resistance is measured by a test using a $4.2 \mathrm{~kg}$ mass falling onto mid point of (100x100x500 mm) beams from $0.3 \mathrm{~m}$ height, as shown in figure (2). The specimens were experimented until failure (de-bonding fibers and spiral fibers). The energy absorbed by concrete beam, which express impact resistance, is given according to the following relation:

$$
\boldsymbol{E}=\boldsymbol{m}(\mathrm{Kg}) \times \boldsymbol{n} * \boldsymbol{h}(\mathrm{m}) \times \boldsymbol{g}\left(\mathrm{m} / \mathrm{sec}^{2}\right) \quad N . m
$$

Where: $\boldsymbol{E}$ is the energy absorbed during Impact by concrete expressed in (N.m).

$\boldsymbol{m}$ is the mass of the falling weight expressed in $(\mathrm{Kg})$.

$n$ number of blows.

$\boldsymbol{h}$ is the height which equal to the summation of heights to failure expressed in $(m)$.

$\boldsymbol{g}$ is the acceleration of the gravity expressed in $\left(\mathrm{m} / \mathrm{sec}^{2}\right)$.
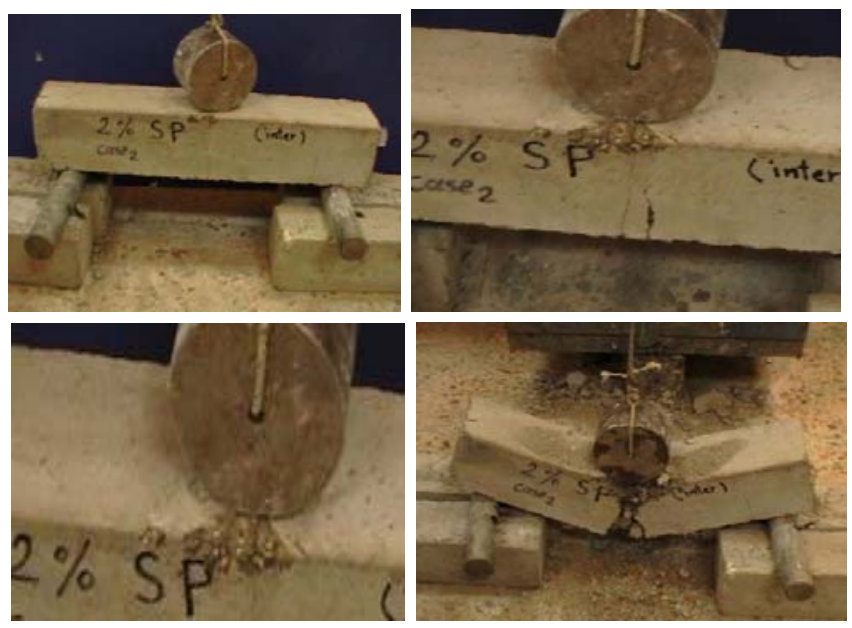

Figure (2) Impact Resistance Test 


\section{Penetration resistance test}

The Gas gun tests were carried out to investigate the penetration resistance of concrete specimens opposed to ballistic impact (very high velocity of missile) as shown in Figure (3).

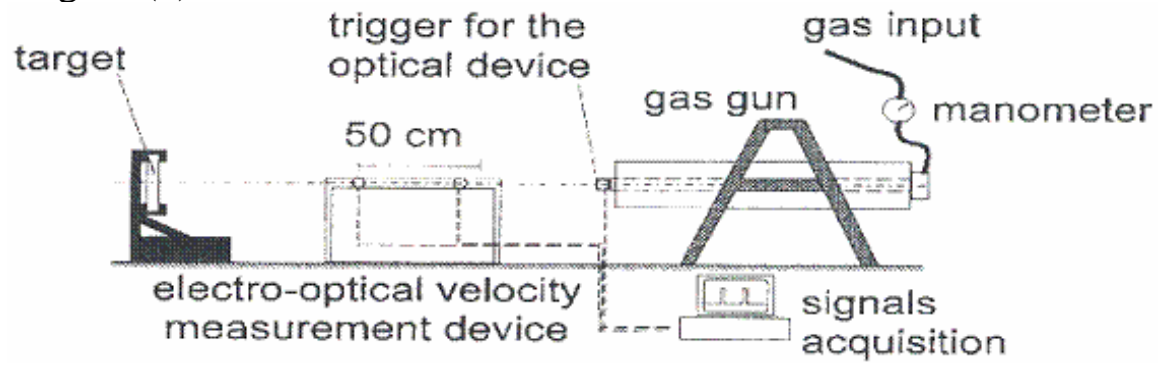

Figure (3) Gas Gun Test

This test was carried out according to standards of USA army corps of engineering (ACE). Different calibers of missiles using different cannons were used in spite of pressure chamber existed in Gas gun as detailed in next table (3).

Table (3) Specifications of different missiles used in Gas Gun test

\begin{tabular}{|c|c|c|c|l|c|}
\hline $\begin{array}{c}\text { Caliber of } \\
\text { missile } \\
(\mathrm{mm})\end{array}$ & $\begin{array}{c}\text { Missile } \\
\text { type }\end{array}$ & $\begin{array}{c}\text { Maximum } \\
\text { penetration in } \\
\text { steel }(\mathrm{cm})\end{array}$ & $\begin{array}{c}\text { Muzzle } \\
\text { velocity } \\
(\mathrm{m} / \mathrm{s})\end{array}$ & Armament & $\begin{array}{c}\text { Brinell } \\
\text { hardness } \\
\text { number } \\
(\mathrm{BHN})\end{array}$ \\
\hline $23 \mathrm{~mm}$ & API & $5 \mathrm{Cm}$ & 980 & Aircraft 23mm Gun & 300 \\
\hline $14.5 \mathrm{~mm}$ & AP & $4 \mathrm{Cm}$ & 975 & $14.5 \mathrm{~mm}$ Canon & 300 \\
\hline $12.7 \mathrm{~mm}$ & AP & $2.5 \mathrm{Cm}$ & 875 & $12.7 \mathrm{~mm}$ Canon & 300 \\
\hline
\end{tabular}
piercing.

In this investigation $23 \mathrm{~mm}$ round which is piercing for armors and concrete structures was used, and was fired using Aircraft Gun as shown in figure (4).
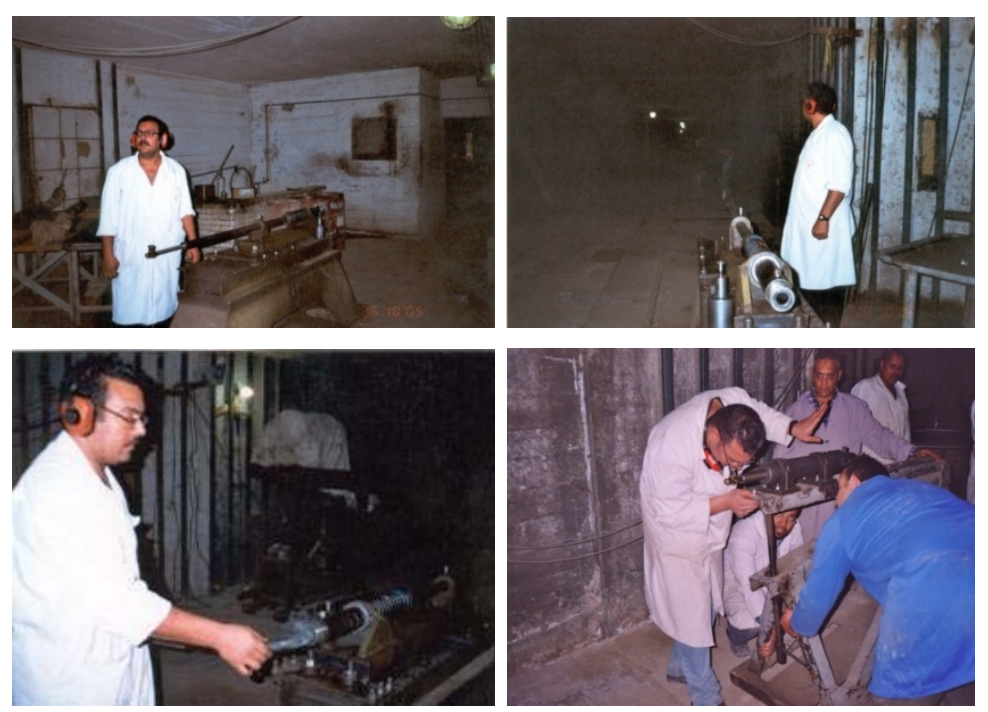

Figure (4) Aircraft $23 \mathrm{~mm}$ cannon

The maximum muzzle velocity of this missile is 980 mps. The velocity was measured using electro-optical velocity measurement device which had connected with computer. The results carried out automatically as shown in figure (5). 

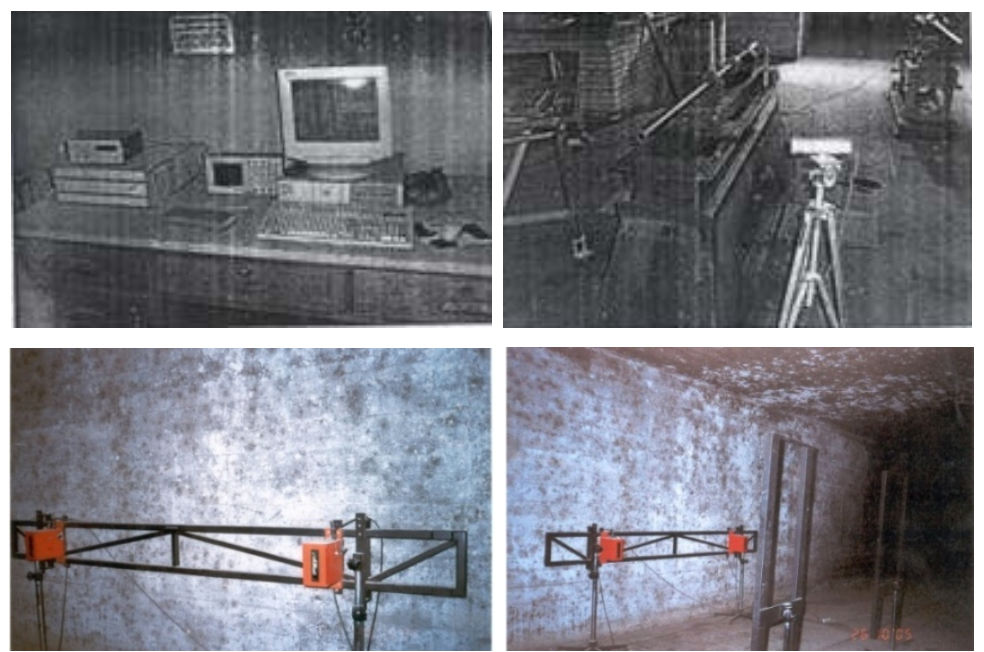

Figure (5) Velocity measurement device

Fig.(6) shows the $23 \mathrm{~mm}$ round (API) at different stages of its firing as follows:

- Stage (I):

Before firing where the round weighs $453 \mathrm{gm}$.

- Stage (II):

After firing and before impacting where the projectile and its balancing nose weigh $190 \mathrm{gm}$.

- Stage (III):

After impacting where the projectile "which penetrates target" weighs $175 \mathrm{gm}$.

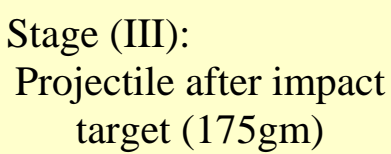

Stage (II):

Missile after firing (190gm)

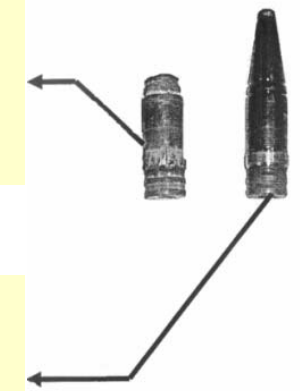

$\longleftarrow$

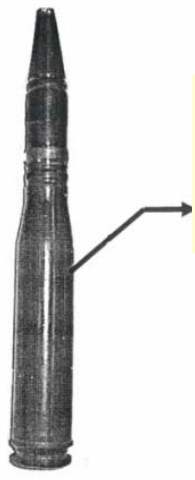

Stage (I):

23mm API round

(453gm)

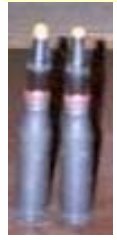

Figure (6) Different firing stages of 23mm API missile

The specimens in this test were plates (slabs) of dimensions (500x500x200 mm) to avoid the effect of ends of specimens throw penetration, where the smallest dimension of opposed area of specimen should be $\geq 20 \mathrm{~d}$ "diameter of projectile". So, the dimensions of area opposed to $23 \mathrm{~mm}$ round were (500 x $500 \mathrm{~mm})$.

The plate were mounted on a stationary stiff steel frame (figure 7) in front of the Gun as far as $50 \mathrm{~m}$ where the surface $(500 \times 500 \mathrm{~mm})$ was normal to the missile path and the thickness $(200 \mathrm{~mm})$ was parallel to path of missile. These specimens were supported by the steel frame along their perimeter to prevent movement in both directions. There is no special measures were taken to provide fully fixed boundary conditions, which has no effect on the penetration process due to the very high velocity of missile (the boundary conditions considered is simply supported). 

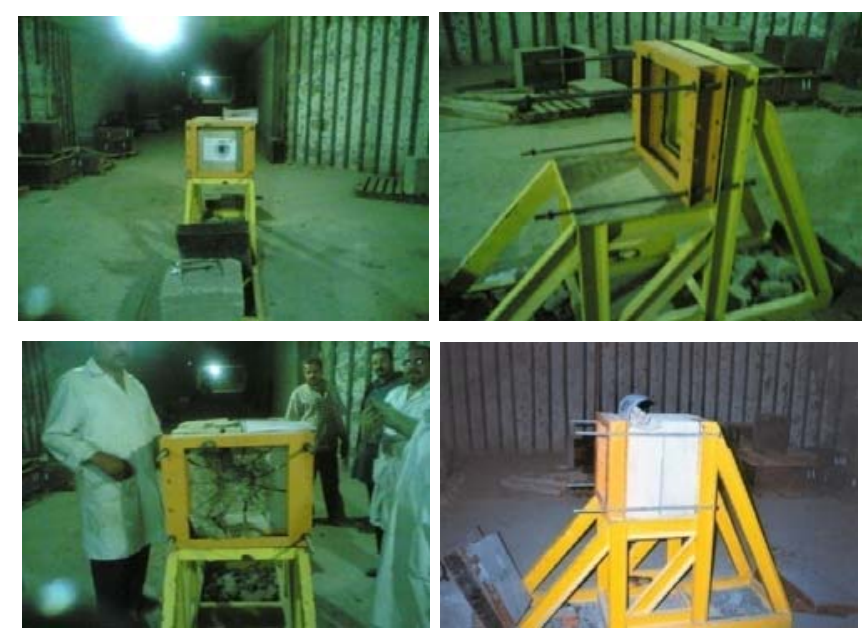

Figure (7) Specimens Mounted on Stiff Steel Frame

\section{Comparison between different Air-craft bombs and 23mm missile:}

Comparing the round $23 \mathrm{~mm}$ used in this test and some different Air-craft bombs used against fortification and buried structures as shown in table (4), it was found that loading of projectile of $23 \mathrm{~mm}$ approximately converges to those of most bombs mentioned next [5].

Table (4) Effects of 23mm missile and different Air-craft bombs [5]

\begin{tabular}{|c|c|c|c|c|c|c|c|c|}
\hline \multicolumn{2}{|c|}{ Type (caliber) } & \multirow{2}{*}{$\begin{array}{c}\text { Bomb } \\
\text { 250lb } \\
\text { MK81 } \\
118\end{array}$} & \multirow{2}{*}{$\begin{array}{c}\text { Bomb } \\
500 l b \\
\text { MK82 } \\
241\end{array}$} & \multirow{2}{*}{$\begin{array}{c}\text { Bomb } \\
1000 l b \\
\text { MK83 } \\
447\end{array}$} & \multirow{2}{*}{$\begin{array}{c}\text { Bomb } \\
2000 \mathrm{lb} \\
\text { MK84 } \\
894\end{array}$} & \multirow{2}{*}{$\begin{array}{c}\text { Bomb } \\
\text { PB } \\
500-A 1 \\
425\end{array}$} & \multirow{2}{*}{$\begin{array}{c}\text { Bomb } \\
\text { GBU-28 } \\
2130\end{array}$} & \multirow{2}{*}{$\begin{array}{c}\begin{array}{c}\text { Round } \\
23 \mathrm{~mm}\end{array} \\
\text { API }\end{array}$} \\
\hline $\begin{array}{l}\text { Weight } \\
\text { (W) }\end{array}$ & $(\mathrm{Kg})$ & & & & & & & \\
\hline $\begin{array}{l}\text { Diameter } \\
\text { (d) }\end{array}$ & $(\mathrm{Cm})$ & 22.9 & 28 & 35.5 & 45.7 & 27.2 & 37 & 2.3 \\
\hline $\begin{array}{l}\text { Cross } \\
\text { section } \\
\text { area }(\mathrm{A}) \\
\end{array}$ & $\left(\mathrm{Cm}^{2}\right)$ & 410 & 614 & 994 & 1638 & 580 & 1075 & 4.15 \\
\hline \multicolumn{2}{|c|}{$\begin{array}{l}\text { Impact velocity }(\mathrm{V}) \\
(\mathrm{m} / \mathrm{s})\end{array}$} & 260 & 260 & 260 & 260 & 260 & 260 & 960 \\
\hline \multicolumn{2}{|c|}{$\begin{array}{l}\text { Penetration depth } \\
\text { (X) (m) }\end{array}$} & 1.00 & 1.30 & 1.50 & 1.90 & 2.20 & 5.77 & 0.60 \\
\hline \multicolumn{2}{|c|}{$\begin{array}{c}\text { Kinetic energy } \\
\left(\text { Kgf.m) } \times 10^{3}\right. \\
\text { K.E }=0.5 \mathrm{mv}^{2}\end{array}$} & 407 & 830 & 1540 & 3080 & 1464 & 7338 & 8.22 \\
\hline \multicolumn{2}{|c|}{$\begin{array}{c}\text { Impact force } \\
\text { (Kgf) } \times 10^{3} \\
\mathrm{~F}=\mathrm{K} . \mathrm{E} / \mathrm{X} \\
\end{array}$} & 407 & 638 & 1026 & 1621 & 665 & 1270 & 13.7 \\
\hline \multicolumn{2}{|c|}{$\begin{array}{c}\text { Impact pressure } \\
\left(\mathrm{Kgf} / \mathrm{Cm}^{2}\right) \\
\mathrm{P}=\mathrm{F} / \mathrm{A}\end{array}$} & 992 & 1040 & 1033 & 990 & 1146 & 1181 & 3300 \\
\hline \multicolumn{2}{|c|}{$\begin{array}{l}\text { Loading of } \\
\text { projectile } \\
\text { K.E / A } \\
(\mathrm{Kgf} / \mathrm{m}) \times 10^{5}\end{array}$} & 99 & 135 & 155 & 188 & 252 & 682 & 198 \\
\hline
\end{tabular}

Work done $=$ Kinetic energy (K.E)

$\mathrm{F} * \mathrm{X}=0.5 \mathrm{mv}^{2}$ 
Kgf $=1 / 9.81 \mathrm{Kg} \cdot \mathrm{m} / \mathrm{s}^{2}$

Gravity acceleration $(\mathrm{g})=9.81 \mathrm{~m} / \mathrm{s}^{2}$

\section{Results}

\section{Compressive Strength}

Table (5) and Figures (8), and (9) illustrate compressive strength test results.

Table (5) Compressive Strength Test Results and Strength-Enhancement

\begin{tabular}{|c|c|c|c|c|}
\hline \multirow{2}{*}{$\begin{array}{c}\text { Fiber volume } \\
\text { fraction } \\
(\%)\end{array}$} & $\begin{array}{c}\text { Compressive } \\
\text { strength } \\
\left(\mathrm{Kg} / \mathrm{cm}^{2}\right)\end{array}$ & $\begin{array}{c}\text { Strength } \\
\text { enhancement } \\
(\%)\end{array}$ & $\begin{array}{c}\text { Compressive } \\
\text { strength } \\
\left(\mathrm{Kg} / \mathrm{cm}^{2}\right)\end{array}$ & $\begin{array}{c}\text { Strength } \\
\text { enhancement } \\
(\%)\end{array}$ \\
\hline 0.0 & 340 & - & 340 & - \\
\hline 1.0 & 425 & 25 & 431 & 26.8 \\
\hline 2.0 & 434 & 27.6 & 454 & 33.5 \\
\hline 3.0 & 385 & 13.2 & 471 & 38.5 \\
\hline
\end{tabular}

Strength-enhancement $(\%)=\left(\left(F_{f c}-F_{p c}\right) / F_{p c}\right) \times 100$

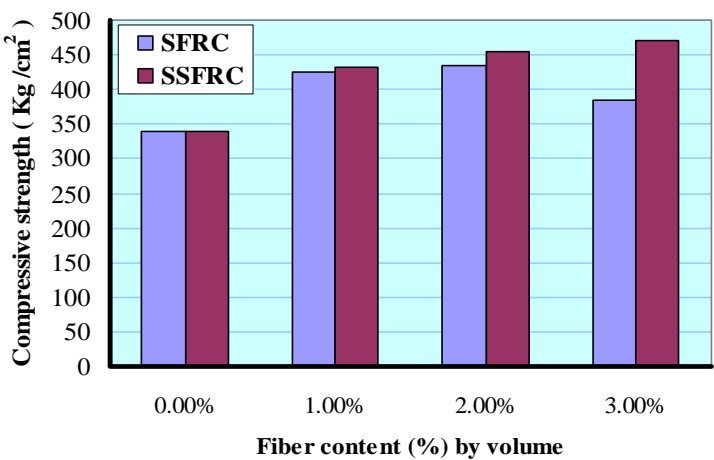

Fig. (8) Relation between comp. strength and fibers contents $(\%)$ by volume

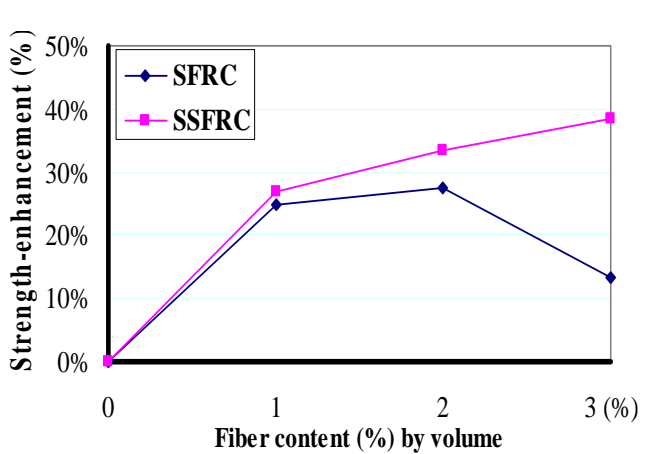

Figure (9) Relative-increase (\%) on compressive strength compared to plain concrete (without fibers) improved $25 \%$ and with $2.0 \%$ fibers content increased to $27.6 \%$, but decreased to $13.2 \%$ with $3.0 \%$ fibers fraction. This means that the improvement in strength doesn't increase significantly with a high content of fibers (3.0\% by volume), perhaps due to the higher air content with fibers in the specimen and due to balling and clumping of fibers. The compressive load increases continually after visible crack on the specimen surface and after achieving the maximum strength then the load of SFC was sustained minute before falling, for few while the compressive loads of plain concrete samples fall down quickly after reaching the maximum value. It is obvious that the addition of steel fibers converts the properties of brittle concrete to a ductile manner.

> Compressive strength of SSFC of $1.0 \%$ fibers content "by volume" increases to $26.8 \%$ compared to plain concrete and increases to $33.5 \%$ and $38.5 \%$ with $2.0 \%$ and $3.0 \%$ fibers contents respectively.This means that the increase in compressive strength was continued with the increase in fibers content, due to the absence of voids, balling, and clumping in spiral fibers.

$>$ There is no significant increase in compressive strength of SSFC compared with that of SFC at the same fibers contents $(1.0 \%, 2.0 \%)$ in both, except with fibers fraction of 3.0\% "by volume" (where the strengths enhancement were $38.5 \%$ and $13.2 \%$ respectively) due to voids and balling in SFC at this high fraction.But this improve of compressive strength with $3.0 \%$ fibers 
content in SSFC is not significant compared to that of $2.0 \%$ " 471,454 $\mathrm{Kg} / \mathrm{cm}^{2}$ respectively" ( if we take workability into account).

\section{Flexural strength (modulus of rupture "MOR")}

Table (6) and in Figures (10) and (11) show MOR results.

Table (6) MOR Test Results and Strength-Enhancement for SFC and SSFC

\begin{tabular}{|c|c|c|c|c|}
\hline \multirow{2}{*}{$\begin{array}{c}\text { Fiber volume } \\
\text { fraction } \\
(\%)\end{array}$} & $\begin{array}{c}\text { Flexural } \\
\text { strength } \\
\left(\mathrm{Kg} / \mathrm{cm}^{2}\right)\end{array}$ & $\begin{array}{c}\text { Strength } \\
\text { enhancement } \\
(\%)\end{array}$ & $\begin{array}{c}\text { Flexural } \\
\text { strength } \\
\left(\mathrm{Kg} / \mathrm{cm}^{2}\right)\end{array}$ & $\begin{array}{c}\text { Strength } \\
\text { enhancement } \\
(\%)\end{array}$ \\
\hline 0.0 & 36 & - & 36 & - \\
\hline 1.0 & 58 & 61 & 40 & 11 \\
\hline 2.0 & 79 & 119.4 & 51.6 & 43.3 \\
\hline 3.0 & 68 & 89 & 62 & 72.2 \\
\hline
\end{tabular}

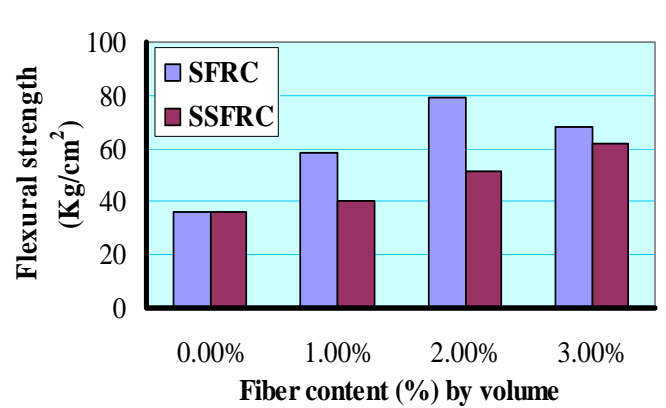

Fig. (10) Relation between flexural strength

(\%) and fibers contents (\%) by volume

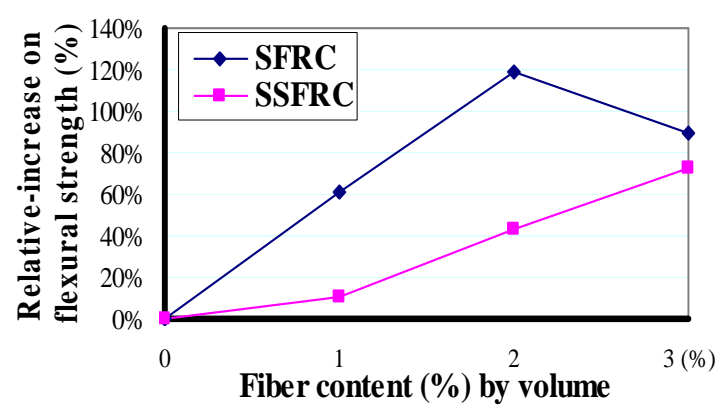

Figure (11) Relative-increase on flexural strength

From results the following conclusions can be observed:

$>$ Flexural strength for SFC improved, with increasing the fiber fraction, from $61 \%$ to $119.4 \%$ with fibers contents $1.0 \%$ and $2.0 \%$, respectively. But the strength decreases to $89 \%$ at $3.0 \%$ fibers content "by volume". This can be attributed to the higher air content with fibers content up to $3.0 \%$.

$>$ Flexural tensile strength for SSFC improved, with increasing the fiber content, from $11 \%$ to $43.3 \%$ to $72.2 \%$ with fibers contents $1.0 \%, 2.0 \%$ and $3.0 \%$, respectively, due to absence of voids, balling, and clumping in spiral fibers.

$>$ Comparing the values of flexural strength in SFC and SSFC there is decreasing in values for SSFC at the similar contents of fibers for SFC. This can be attributed to the spiral steel fibers resist tensile stresses at first crack less than the hooked end steel fibers, due to extending spirals under tensile stresses.

\section{Impact resistance}

The results are reported in Table (7), and Figures (12), (13), (14) and (15).

Table (7) Impact Resistance Test Results and Times of Increase in I.R

\begin{tabular}{|c|c|c|c|c|c|c|c|}
\hline \multirow{2}{*}{$\begin{array}{c}\text { Fiber } \\
\text { volume } \\
\text { fraction } \\
(\%)\end{array}$} & $\begin{array}{c}\text { Initial } \\
\text { cracking }\end{array}$ & Failure & \multicolumn{2}{|c|}{$\begin{array}{c}\text { Times of increase } \\
\text { In I.R }\end{array}$} & $\begin{array}{c}\text { Initial } \\
\text { cracking }\end{array}$ & Failure & $\begin{array}{c}\text { Times of increase } \\
\text { in I.R }\end{array}$ \\
\cline { 2 - 8 } & $\begin{array}{c}\text { I.R } \\
\text { (N.m) }\end{array}$ & $\begin{array}{c}\text { Initial } \\
\text { cracking }\end{array}$ & failure & $\begin{array}{c}\text { I.R } \\
\text { (N.m) }\end{array}$ & $\begin{array}{c}\text { I.R } \\
\text { (N.m) }\end{array}$ & $\begin{array}{c}\text { Initial } \\
\text { cracking }\end{array}$ & failure \\
\hline
\end{tabular}




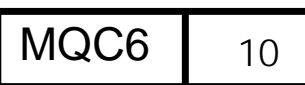

\begin{tabular}{|c|c|c|c|c|c|c|c|c|}
\hline 0.0 & 37.8 & 50.4 & - & - & 37.8 & 50.4 & - & - \\
\hline 1.0 & 101 & 806 & 2.7 & 16 & 126 & 4536 & 3.3 & 90 \\
\hline 2.0 & 202 & 1638 & 5.3 & 32.5 & 151 & 4914 & 4 & 97.5 \\
\hline 3.0 & 176 & 1197 & 4.7 & 23.7 & 151 & 5103 & 4 & 101 \\
\hline
\end{tabular}

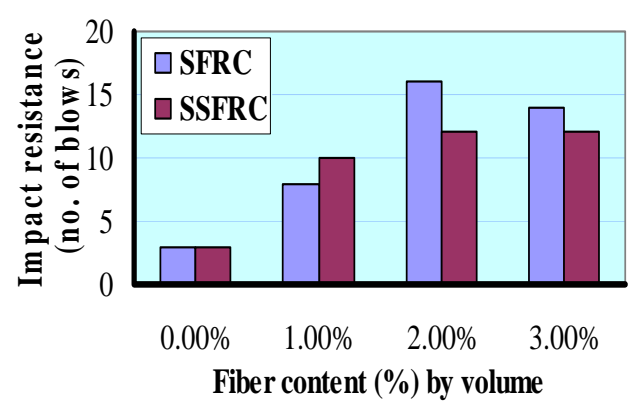

Fig. (12) Impact resistance at initial cracking

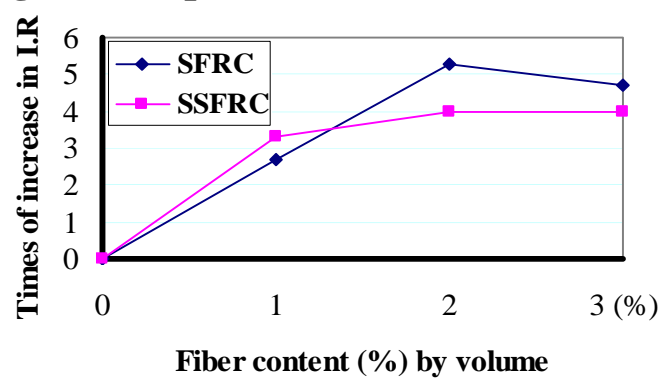

Fig. (14) Times of increase in I.R at first cracking

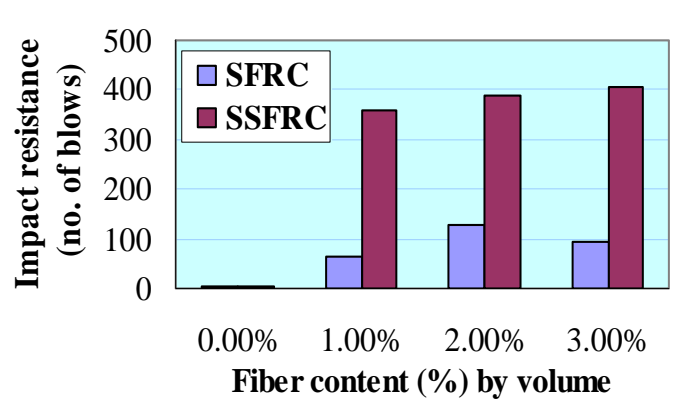

Fig. (13) I.R at failure

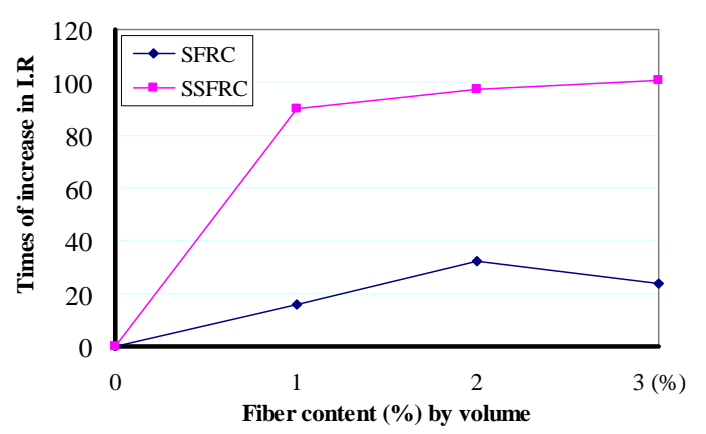

Fig. (15) Times of increase In I.R at failure

$>$ The impact resistance at initial cracking of SFC (compared to plain concrete) increased from about 2.5 times with $1.0 \%$ fibers content by volume to 5 times with $2.0 \%$ fibers content, but decreased to about 4.5 times with fibers content 3.0\%, as shown in figures (12), (14).

$>$ using SSFC, the impact resistance at initial cracking increased from about 3 times with $1.0 \%$ fibers content by volume to 4 times with $3.0 \%$ fibers content by volume, also impact resistance at failure increased greatly from 90 times to 97.5 times to about 100 times with fibers contents $1.0 \%, 2.0 \%$ and $3.0 \%$ by volume, respectively as shown in figures (13), (15). This can be attributed to interlocking spiral fibers together which resist impact loading until de-bonding (fractured) rather than pullout, which means great energy absorption more than other types of fiber reinforced concrete.

\section{Gas Gun results (penetration resistance)}

The results of penetration depth $(\mathrm{x})$ and front crater diameter are recorded in table (8) and illustrated in figures (16), (17), (18), (19).

Table (8) Penetration resistance and front crater diameter results and relative increase in both

\begin{tabular}{|c|c|c|c|c|c|c|c|c|}
\hline \multirow{3}{*}{$\begin{array}{c}\text { Fiber } \\
\text { volume } \\
\text { fraction } \\
(\%)\end{array}$} & \multicolumn{4}{|c|}{ SFC } & \multicolumn{4}{|c|}{ SSFC } \\
\hline & \multirow{2}{*}{$\begin{array}{l}\text { Penetration } \\
\text { depth "x" } \\
\text { (Cm) }\end{array}$} & \multirow{2}{*}{$\begin{array}{c}\text { Front } \\
\text { crater } \\
\text { diameter } \\
(\mathrm{Cm})\end{array}$} & \multicolumn{2}{|c|}{$\begin{array}{c}\text { Reduction } \\
\text { percentage }(\%) \text { in }\end{array}$} & \multirow{2}{*}{$\begin{array}{l}\text { Penetration } \\
\text { depth "x" } \\
\text { (Cm) }\end{array}$} & \multirow{2}{*}{$\begin{array}{c}\text { Front } \\
\text { crater } \\
\text { diameter } \\
(\mathrm{Cm})\end{array}$} & \multicolumn{2}{|c|}{$\begin{array}{c}\text { Reduction } \\
\text { percentage }(\%) \text { in }\end{array}$} \\
\hline & & & $\begin{array}{c}\text { penetration } \\
\text { depth }\end{array}$ & $\begin{array}{c}\text { Front } \\
\text { crater } \\
\text { diameter }\end{array}$ & & & $\begin{array}{l}\text { penetration } \\
\text { depth }\end{array}$ & $\begin{array}{r}\text { Front } \\
\text { crater } \\
\text { diamet }\end{array}$ \\
\hline 0.0 & 40 & Shattering & & - & 40 & Shattering & - & - \\
\hline
\end{tabular}


Proceedings of the 7th ICCAE Conf. 27 -29 May, 2008

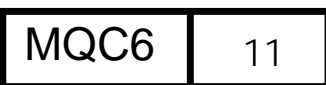

\begin{tabular}{|l|c|c|c|c|c|c|c|c}
\hline & & to pieces & & & & to pieces & & \\
\hline 1.0 & 28.6 & 25 & 28.5 & 50 & 29.5 & 23 & 26.25 & 54 \\
\hline 2.0 & 29.8 & 20 & 25.5 & 60 & 35 & 23 & 12.5 & 54 \\
\hline 3.0 & 39 & 20 & 2.5 & 60 & 37.4 & 15.5 & 6.5 & 69 \\
\hline
\end{tabular}

The results indicated that the hard projectile had rebounded after penetrating the tested plates of fibers contents $1.0 \%$ and $2.0 \%$ "by volume" (in both hooked ends and spirals). But it had stuck in plates of fibers contents 3.0\% "by volume" and perforated from control specimen plates (Plain concrete) after shattering these plates into pieces as shown in figures (16), (17).
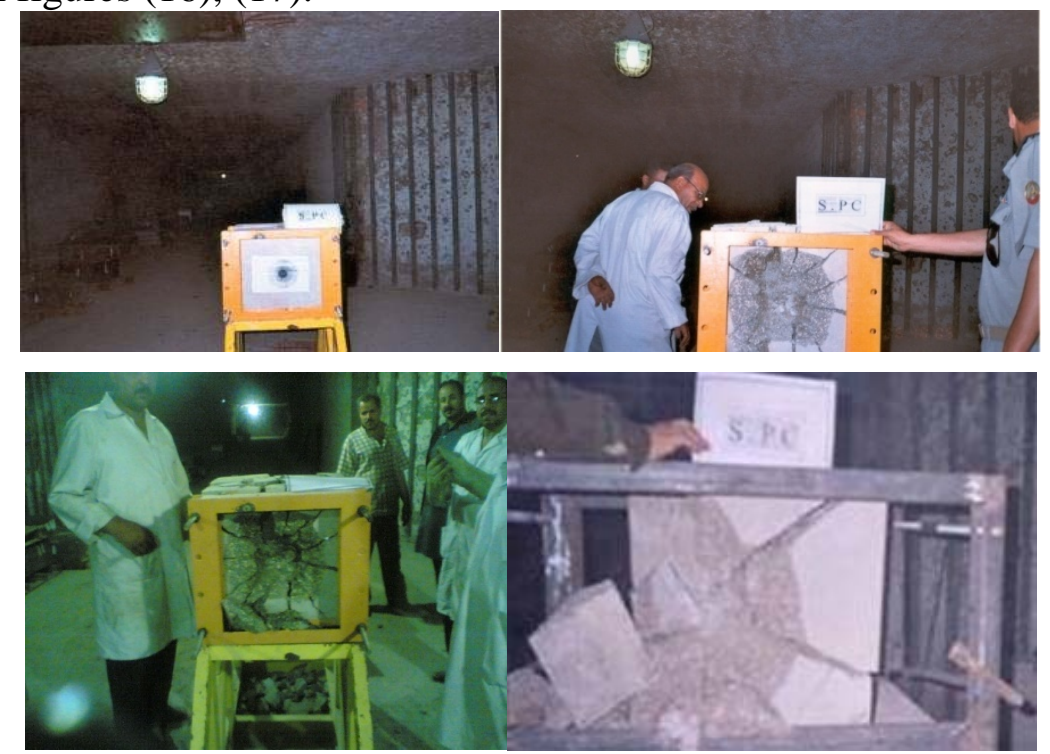

Figure (16) Plain concrete (Control specimen) was shattered into pieces after shooting
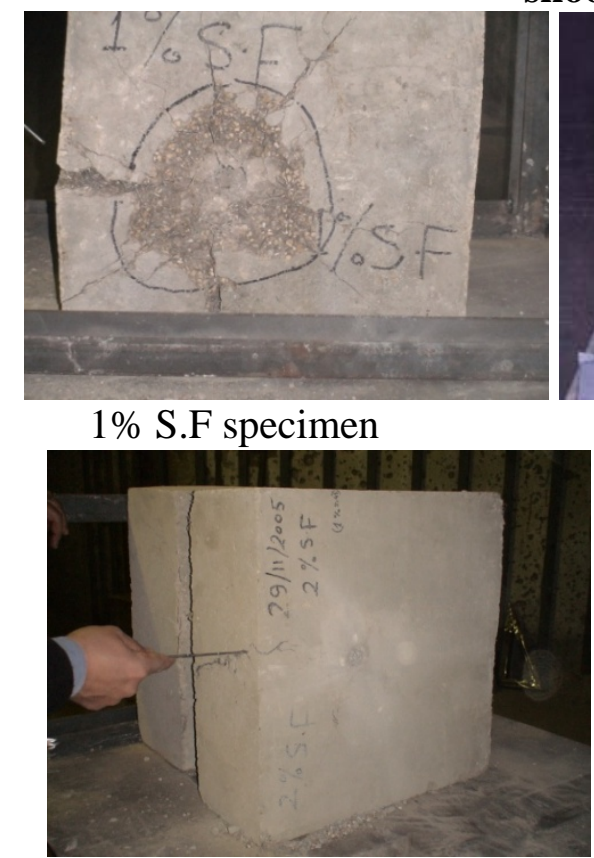

2\% S.F specimen
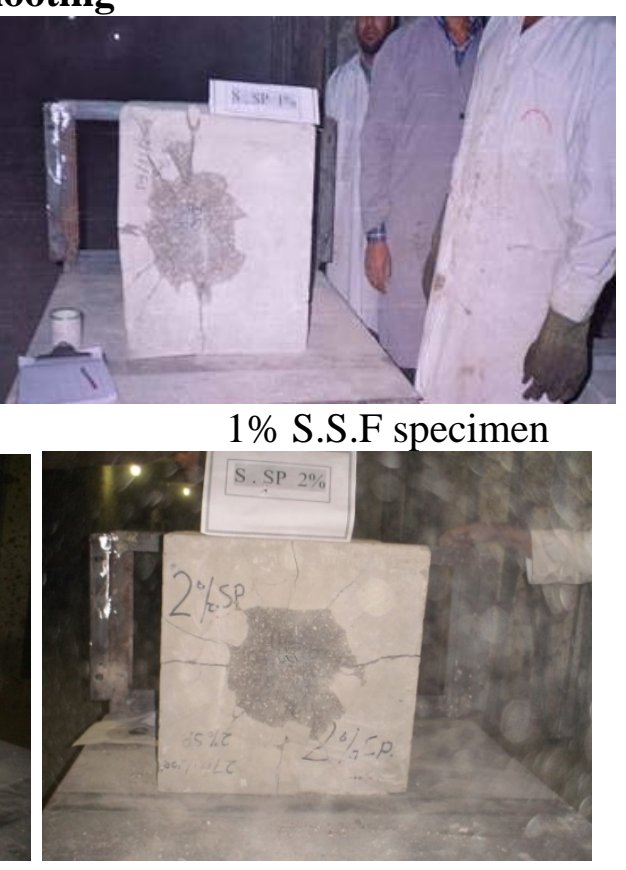

2\% S.S.F specimen 


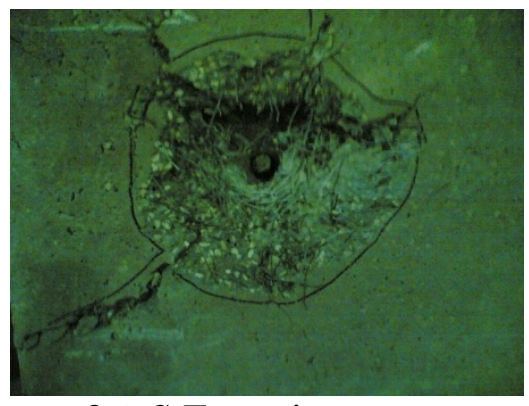

3\% S.F specimen

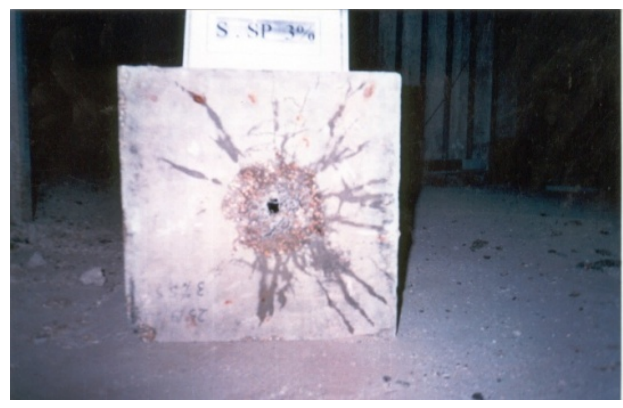

3\% S.S.F specimen

Fig. (17) Projectile had rebounded after penetrating specimens of fiber continents $1 \%$ and $2 \%$ "by volume" but stuck in $3 \%$

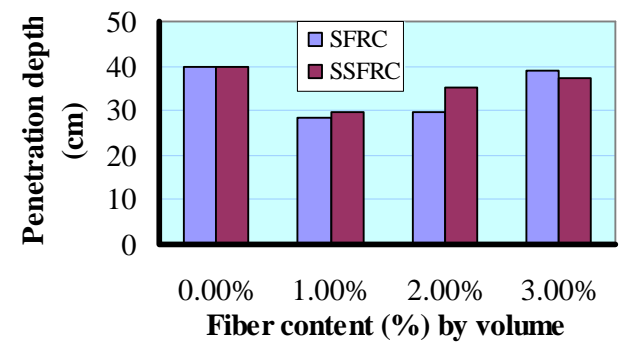

Fig. (18) Relation between penetration penetration depth fibers

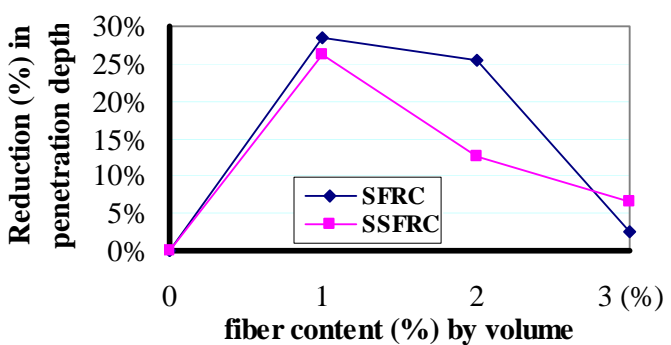

Fig. (19) Reduction (\%) In

with various contents and types of

$>$ Using steel fibers in concrete prevents its shattering, disintegration, and also decreases spalling.

$>$ SFC with $1.0 \%$ fibers content "by volume" reduces penetration depth by about $30 \%$, whereas, there is no significant reduction in penetration depth when increase fibers fraction to $2.0 \%$ "by volume" (compared to $1.0 \%$ fibers content), but there is descending in penetration resistance when increase steel fibers fraction to 3.0\% "by volume" as shown in figures (18) and (19). This may be attributed to low compressive strength of 3.0\% SFRC comparing with compressive strength of lowest steel fibers content or the disadvantage of integrating composite materials (3.0\% SFC) which providing media with less variation in resisting pass of hard projectiles.

$>$ The reduction of penetration depth of Spiral Steel Fiber Concrete is less than that of Steel Fiber Concrete (hooked-ends) as shown in figures (18) and (19).

\section{Mode of front crater}

From the results recorded in table (8) and illustrated in figures (16), (17), (18), and (19) the following conclusions are observed:

$>$ Spiral Steel Fiber reduces front crater than that happen in Steel Fiber (hookedends) specimens.

$>$ Increasing volume content of SF in both two types leads to a decrease in front crater.

$>3 \%$ fiber volume fraction of SF (hooked-ends) doesn't improve resistance of front crater compared to $2 \%$ SF (hooked-ends) volume fraction. 
There is inverse relation ship between depth of penetration and front crater when adding SF (hooked-ends and spirals), whereas, increasing depth of penetration leads to reduce front crater and vice versa as shown in table (8) and figures (20), (21).

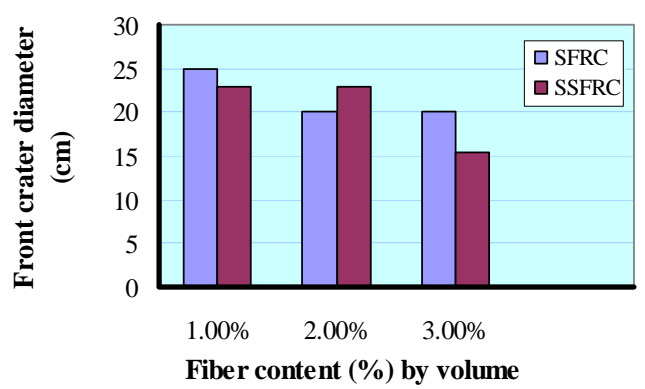

Fig. (20) Relation between front crater diameter (cm) and fibers contents (\%)

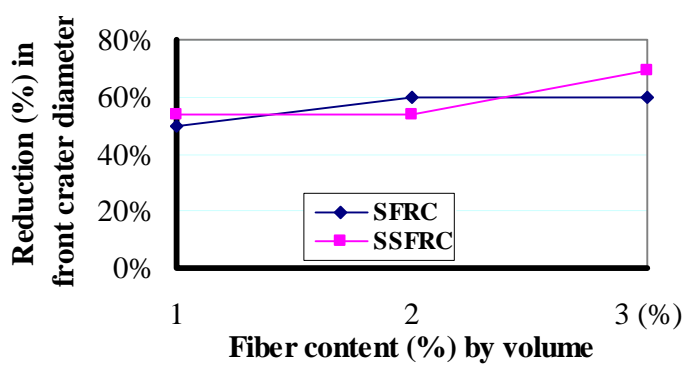

Fig. (21) Reduction (\%) In front crater diameter diameter with various contents and types of fibers

\section{Conclusions}

The following general conclusions could be derived from analyzing the previous results of experimental tests in this study:

1. The optimum fraction of steel fibers to improve penetration resistance under impact of missiles is $1.0 \%$ by volume "where penetration depth reduced about $30 \% "$.

2. Increasing S.F content over $1.0 \%$ "by volume” reduces penetration resistance of concrete due to providing integrating media with less variation to resist penetration pass of missiles.

3. Adding 1.0\% S.F "hooked-ends" to a defender separated layers (Barriers) has enormous benefits to reduce about $30 \%$ of penetration depth due to impact of missiles.

4. Adding Spiral steel fibers (S.S.F) to concrete of defender layers (Barriers) causes more problems of workability and low effects to reduce penetration of missiles comparing with hooked-ends S.F.

5. Interlocking Spiral steel fibers "S.S.F" (made as a grid) has a great effect to improve impact resistance at low speeds impact than the effect of hooked-ends S.F, but it has limited effect in resisting impact of missile "penetration" at very high speeds comparing with reduction of penetration depth when using hooked-ends S.F.

6. The compressive and tensile strength of plain concrete improved by adding steel fibers "hooked-ends" up to $2.0 \%$ by volume, but they began to descend at 3.0\% fibers content "by volume".

7. The improvement in compressive and tensile strength when adding Steel fibers (S.F) with volume fraction over $1.0 \%$ has no significant effect compared to that at $1.0 \%$ steel fibers content "by volume".

8. The improvement of compressive and tensile strength due to adding spiral steel fibers (S.S.F) with $1.0 \%$ "by volume" to plain concrete has no significant effect compared to the improvement when adding steel fibers "hooked-ends" at the same volume content (1.0\%). 
9. As Steel fibers (S.F) contents increases $(1.0 \%, 2.0 \%, 3.0 \%)$ there was an enhancement in modulus of rupture (MOR), but the enhancement decreases when adding Spiral steel fibers (S.S.F) at the same fibers content.

\section{Recommendations}

The following recommendations could be investigated for future works:

1. Evaluation the performance of mixes with hooked-ends steel fibers contents as $0.25 \%, 0.5 \%$ and $0.75 \%$ subject to impact of missiles to obtain the optimum fiber content.

2. Studying a numerical model using software program to simulate concrete behavior under impact of missiles.

3. Studying the effects of adding other local additives as polypropylene fibers and other kinds of gravels as basalt with S.F and crushed dolomite stone to overcome the low variation of media which resist penetration pass of missile.

\section{References}

[1] Neville, A.M., "Properties of Concrete", $3^{\text {rd }}$ Edition, London Scientific and Technical, 1981.

[2] Sidney Mindess and J.Francis Young, "Concrete", PRENTIC-HALL, INC. Englewood Cliffs, New Jersey 07632, 1981.

[3] D. J. Hannant, "Fiber Cements and Fiber Concretes", JOHN WILEY \& SONS, Chichester.New York. Brisbane.Toronto, 1978.

[4] ConWep "Conventional Weapons Effects", U. S. Army Engineer Waterways Experiment Station, 3909 Halls Ferry Road, Vicksburg, 13 Dec 1991.

[5] Ahmed A. Fouda, "Increase of Fortifying Ability of Fortifications \& Command Centers to Resist Penetration of Missiles”, Engineer Corps of Egyptian Army Forces, Technical Thesis No. (211307), November 2004.

[6] Anil K. Kar, "Projectile Penetration Into Buried Structures”, Journal of The Structural Division, Jan. 1978, Vol. 104, No. ST1, pp 125-138.

[7] George E. Sliter, "Assessment of Empirical Concrete Impact Formulas", Journal of The Structural Division, May 1980, Vol. 106, No. ST5, pp 1023-1043.

[8] Achintya Haldar, and Hussien A. Hamieh, "Local Effect of Solid Missiles on Concrete Structures”, Journal of Structural Engineering, May 1984, Vol. 110, No. 5, pp 948959.

[9] Ernest K. Schrader, "Impact Resistance and Test Procedure for Concrete", ACI Materials Journal, March- April 1981, Vol. 78, No. 2, PP. 141-146.

[10] Sidney Mindess, Arnon B., Cheng Yan, and Gary Vondran, "Impact Resistance of Concrete Containing both Conventional Steel Reinforcement and Fibrillated Polypropylene Fibers”, ACI Materials Journal, November- December 1989, Vol. 86, No. 6, PP. 545-549.

[11] Nemkumar Banthia, Sidney Mindess, and J.-F. Trottier, "Impact Resistance of Steel Fiber Reinforced Concrete”, ACI Materials Journal, September-October 1996, Vol. 93, No. 5, pp 472-479.

[12] N. Banthia, Cheng Yan, and K. Sakai, "Impact Resistance of Concrete Plates Reinforced with a Fiber Reinforced Plastic Grid”, ACI Materials Journal, January 
1998, Vol. 95, No. 1, pp 11-18.

[13] Vivek B., Nemkumar Banthia, and Brendt Aarup, "Impact Response of Ultra-HighStrength Fiber-Reinforced Cement Composite”, ACI Materials Journal, Vol. 99, No. 6, November 1, 2002.

[14] Mohamed H. Hassoun, "Introducing a New Shape of Steel Fibers and Studying its Effect on the Mechanical Properties of Concrete”, M.Sc. thesis, Military Technical College, Cairo, Egypt, 2005.

[15] Avraham N. Dancygier, David Z. Yankelevsky, and Hadassa Baum, "Behavior of Reinforced Concrete Walls With Internal Plaster Coating Under Exterior Hard Projectile Impact”, ACI Materials Journal, January-February 1999,Vol. 96, No. 1, pp 116-125.

[16] Avraham N. Dancygier, and David Z. Yankelevsky, "Effects of Reinforced Concrete Properties on Resistance to Hard Projectile Impact”, ACI Structural Journal, MarchApril 1999, Vol. 96, No. 2, PP. 259-267.

[17] Ahmed Hassan Mohamed Hassan, "Stress Analysis of Composite Materials", M.Sc. thesis, Military Technical College, Cairo, Egypt, 2004.

[18] Master Chemicals Technology, Address: 23 Al-Tahrir St., Dokki. ,Cairo, Egypt, MCSuper 43 "Concrete Superplasticizer and Set Retarder”, Sheet No.1, 2004.

[19] Avraham N. Dancygier, "Rear Face Damage of Normal and High-Stress Concrete Elements Caused by Hard Projectile Impact”, ACI Structural Journal, May-June 1998, Vol. 95, No. 3, PP. 291-267. 